http://dx.doi.org/10.11646/phytotaxa.161.1.2

\title{
A new hybrid from Taiwan, Elatostema $\times$ hybrida (Urticaceae), is the first confirmed natural hybrid for Urticaceae
}

\author{
YU-HSIN TSENG ${ }^{1} \&$ JER-MING HU ${ }^{1,2}$ \\ 1. Institute of Ecology and Evolutionary Biology, National Taiwan University, Taipei, Taiwan 106 \\ 2.Author for correspondence, jmhu@ntu.edu.tw
}

\begin{abstract}
Explosive pollen dispersal is common in Urticaceae and they are thought to be wind-pollinated. Despite a lack of obvious mechanism for preventing cross-species pollination, putative hybrid species in Urticaceae are rarely documented. Here we described the first natural hybrid in Urticaceae Elatostema $\times$ hybrida from Taiwan. Morphological characters in E. $\times$ hybrida are intermediate between putative parental species: E. lineolatum var. majus and E. platyphylloides. Six hybrid populations of E. ×hybrida were found in Taiwan that exhibited largely overlapping distribution patterns with its putative parents. Phylogenetic analysis of chloroplast DNA showed that the hybrid species is more closely related to E. lineolatum var. majus suggesting that the latter is the maternal parent and that hybridization is unidirectional. The chromosome number of $E$. $\times$ hybrida remains the same as its putative parents $(2 n=26)$. We speculate that the examined hybrids are natural first-generation results of independent hybridization events. Based on the morphology, spatial distribution, DNA sequence data, pollen viability and cytological observations, we hypothesize that E. $\times$ hybrida is derived from natural hybridization events between E. lineolatum var. majus ( $($ ) and E. platyphylloides (ठ).
\end{abstract}

Key words: Natural hybridization, molecular data, morphology, nrITS, trnH-psbA spacer, first-generation hybrid, Elatostema lineolatum var. majus, Elatostema platyphylloides

\section{Introduction}

Hybridization has been demonstrated to be an important force in plant evolution for forming new species (Gross \& Rieseberg 2005, Soltis \& Soltis 2009). Compared to the more commonly occurring allopolyploid hybrid speciation (genome doubling), homoploidy hybrid speciation which has no impact on chromosome number is relatively rare (Abbott et al. 2010). Although the occurrence of natural hybridization is recognized as a common feature in many flowering plants, they are more commonly documented in some families: Asteraceae, Poaceae and Cyperaceae than in others: Santalaceae, Linaceae, Hydrocharitaceae and Urticaceae (Ellstrand et al. 1996, Whitney et al. 2010).

The Urticaceae consists of ca. 54 genera and 2,600 species (including Cecropiaceae) (APG II 2003, APG III 2009) and is widely distributed from tropical to temperate regions with a centre of diversity in tropical Asia. Most Urticaceae species have minute unisexual flowers with a reduced perianth, which makes hypotheses of morphological homology very difficult (Monro 2006). The majority of Urticaceae genera have stamens that are inflexed in bud and release pollen explosively through a dramatic reflex motion that may be facilitated by wind.

Despite a lack of obvious morphological mechanism for preventing cross-species pollination amongst the 2,600 Urticaceae species, only few possible hybrid species have been recorded in this poorly studied family. Yahara (1983) documented putative hybridization between Boehmeria gracilis Wright (1899: 485) and an apomictic race of B. japonica Miquel (1867: 131) on Mt. Higashiakashi, Japan, which included both triploid and tetraploid individuals. Another possible hybrid in Elatostema Forster \& Forster (1776: 105) was recorded occurring in a greenhouse between two endemic Japanese species, E. oshimense (Hatusima) Takasi Yamazaki (1972: 180) and E. yonakuniense Hatusima (1963: 34) (Kanemoto 1997). Based on a survey of four North American regions, British 
parental genome may be preserved in the hybrid. Therefore the maintenance of partial and uneven homogenization of parental sequences in the six populations of putative hybrid may be due to an unequal tempo of concerted evolution of nrITS sequences among different population and individuals.

The result from the chloroplast DNA phylogeny infers a possible direction of hybridization since the inheritance of chloroplast DNA is assumed to be maternal for most angiosperms (Gillham 1978, Sears 1980) and has been demonstrated for Pilea Lindley (1821: tab. 4) and Urtica Linnaeus (1753b: 983) of Urticaceae (Zhang et al. 2003). Although the direction of chloroplast inheritance in this instance cannot be confirmed, we postulate that E. lineolatum var. majus is the maternal parent and E. platyphylloides is the paternal parent for the reason given above.

Although E. $\times$ hybrida is an F1 hybrid and the establishment of the F1 generation is only the first step in a possible speciation through hybridization, the reduction of fertility in F1 hybrids is a barrier to introgression between parental species. Novel fertile hybrid species may be established after backcrossing or interbreeding among F1 hybrids via the few viable gametes (Grant 1958, Arnold \& Hodges 1997). Hybrid inviability and sterility can also play important roles in the process of speciation by acting as reproductive isolating barriers (Coyne \& Orr 2004).

Each naturally occurring hybrid species needs individual evaluation in order to determine its conservation status if this hybridization event is not driven by anthropogenic activity and one of parental species involved is not endangered (Genovart 2009). Moreover, hybrids may contain the last remaining genes and perform the ecosystem function of parental species (Rhymer 2008). Arnold et al. (1999) also suggested that hybridization may result in genetic enrichment of the involved populations and facilitates habitat expansion. However, only six populations and less than 100 individuals of E. xhybrida have been found in the field to date. Any conservation strategy would need to take into account on this threat-facing F1 status of the species.

Furthermore, E. ×hybrida is also the first confirmed natural hybrid in Urticaceae by the morphological, cytological and molecular data. Urticaceae has long been a taxonomically difficult group, presumably because of obscured morphological distinction and species richness. It should be noted that few and even absences of hybrid are found in herbarium collections and studies (Ellstrand et al. 1996, Whitney et al. 2010) probably because Urticaceae is a poorly studied family. Too little data are available to understand the occurrence of hybrid in Urticaceae and further research is needed in order to devise a proper conservation strategy. Accurate detection of hybrids has important implications for species conservation, but general botanical collecting maybe not be adequate to document hybridization events. An integrative approach combining morphological and molecular data will prove valuable in the analysis of potential hybridization events. In fact, there are some characters in Urticaceae taxonomy that likely provide clues about the presence of other potential hybrids. For example the morphologically diverse microspecies are easy to find in Urticaceae and these may be the result of introgression between hybrid and related species known to hybridize in nature. Apomictic plants have also been found in some genera of Urticaceae e.g. Elatostema and Procris (Fagerlind 1944), and the close association between hybridization and apomixis may also imply the existence of "cryptic" hybrids in Urticaceae.

\section{Acknowledgements}

We gratefully thank TAI, TAIF, HAST, FRIM, IBK, MO, TNM, K, BM herbaria for providing plant materials, Chun-Kuei Liao for the line drawing, and Bing-Ling Shih and Chien-Hung Yang for assistance in the fieldwork. We also thank Meng-Ying Tsai for the help of pollen viability test, Fen-Ming Lee for the advice of chromosome preparation, Huan-Yu Lin and Yi-Ru Cheng for assistance in data analysis.

\section{Reference}

Abbott, R.J., Hegarty, M.J., Hiscock, S.J. \& Brennan, A.C. (2010) Homoploid hybrid speciation in action. Taxon 59: 13751386.

Albini, S.M. (1994) A karyotype of the Arabidopsis thaliana genome derived from synaptonemal complex analysis at prophase I of meiosis. Plant Journal 5: 665-672. http://dx.doi.org/10.1111/j.1365-313x.1994.00665.x 
APG II (2003) An update of the Angiosperm Phylogeny Group classification for the orders and families of flowering plants: APG II. Botanical Journal of the Linnean Society 141: 399-436.

http://dx.doi.org/10.1046/j.1095-8339.2003.t01-1-00158.x

APG III (2009) An update of the Angiosperm Phylogeny Group classification for the orders and families of flowering plants: APG III. Botanical Journal of the Linnean Society 161: 105-121.

http://dx.doi.org/10.1111/j.1095-8339.2009.00996.x

Arft, A.M. \& Ranker, T.A. (1998) Allopolyploid origin and population genetics of the rare orchid Spiranthes diluvialis. American Journal of Botany 85: 110-122. http://dx.doi.org/10.2307/2446560

Arnold, M.L. \& Hodges, S.A. (1997) Are natural hybrids fit or unfit relative to their parents? Trends in Ecology and Evolution 10: 67-71. http://dx.doi.org/10.1016/s0169-5347(00)88979-x

Arnold, M.L., Bulger, M.R., Burke, J. M., Hempel, A.L. \& Williams, J.H. (1999) Natural hybridization: how low can you go and still be important? Ecology 80: 371-381. http://dx.doi.org/10.2307/176618

Bentham, G. (1861) Urticaceae. In: Bentham, G. (ed.) Flora Hongkongensis. Lovell L. Reeve, London, pp. $323-333$.

Bentham, G. (1876) Gesneriaceae. In: Bentham, G. \& Hooker, J.D. (eds.) Genera Plantarum 2(2). Lovell Reeve \& Co., London, pp. 990-1025.

Chiou, C.R., Hsieh, C.F., Wang, J.C., Chen, M.Y., Liu, H.Y., Yeh, C.L., Yang, S.Z., Chen, T.Y., Hsia, Y.J. \& Song, G.Z.M. (2009) The first national vegetation inventory in Taiwan. Taiwan Journal of Forest Science 24: 295-302.

Coyne, J.A. \& Orr, H.A. Speciation. Sinauer, Sunderland, Massacusetts, 545 pp.

Denduangboripant, J., Cronk, Q.C.B., Kokubugata, G. \& Möller, M. (2007) Variation and inheritance of nuclear ribosomal DNA clusters in Streptocarpus (Gesneriaceae) and their biological and phylogenetic implications. International Journal of Plant Sciences 168: 455-467. http://dx.doi.org/10.1086/512103

Ellstrand, N.C., Whitkus, R. \& Rieseberg, L.H. (1996) Distribution of spontaneous plant hybrids. Proceedings of the National Academy of Sciences, USA 93: 5090-5093. http://dx.doi.org/10.1073/pnas.93.10.5090

Fagerlind, F. (1944) Die Samenbildung und die Zytologie bei agamospermischen und sexuellen Arten von Elatostema und einigen nahestehenden Gattungen nebst Beleuchtung einiger damit zusammenhängender Probleme. Kungliga Svenska Vetenskapsakademiens Handlingar 4: 1-130.

Feulgen, R. \& Rossenbeck, H. (1924) Mikroskopisch-chemischer Nachweis eine Nucleinsaure vom Typus der Thymonucleinsaure und die darauf beruhende elektive Farbung von Zellkern in mikroskopischen Praparaten. Zeitschrift für physikalische Chemie, Stöchiometrie und Verwandtschaftslehre 135: 303-348. http://dx.doi.org/10.1515/bchm2.1924.135.5-6.203

Forster, J.R. \& Forster, G. (1776) Elatostema. In: White, B., Cadell, T. \& Elmsly, P. (eds.) Characteres generum plantarum. Ed 2. White, B., Cadell, T. \& Elmsly, P., London, pp. 105-106, pl. 53. http://dx.doi.org/10.5962/bhl.title.4448

Franzke, A. \& Mummenhoff, K. (1999) Recent hybrid speciation in Cardamine (Brassicaceae)-conversion of nuclear ribosomal ITS sequences in statu nascendi. Theoretical and Applied Genetics 98: 831-834. http://dx.doi.org/10.1007/s001220051140

Friis, I. (1993) Urticaceae. In: Kubitzki, K., Rohwer J.G. \& Bittrich, V. (eds.) The families and genera of vascular plants: flowering plants-dicotyledons. Magnoliid, hamamelid and caryophyllid families. Springer-Verlag, Berlin, pp. 612-630. http://dx.doi.org/10.2307/1222750

Gaudichaud, C. (1830) Botanique, part 12. In: Freycinet, H.L.C. de (ed.) Voyage autour du monde... executé sur les corvettes de S. M. l'Uranie et la Physiciene. Pilet-Ainé, Paris, pp. 494. http://dx.doi.org/10.5962/bhl.title.15862

Genovart, M. (2009) Natural hybridization and conservation. Biodiversity and Conservation 18: 1435-1439. http://dx.doi.org/10.1007/s10531-008-9550-x

Gillham, N.W. (1978) Organelle Heredity. Reven Press, New York, 602 pp.

Grant, V. (1958) The regulation of recombination in plants. Cold Spring Harbor Symposia on Quantitative Biology 23: 337363. http://dx.doi.org/10.1101/sqb.1958.023.01.034

Gross, B.L. \& Rieseberg, L.H. (2005) The ecological genetics of homoploid hybrid speciation. Journal of Heredity 96: 241252. http://dx.doi.org/10.1093/jhered/esi026

Hadiah, J.T. \& Conn, B.J. (2009) Usefulness of morphological characters for infrageneric classification of Elatostema (Urticaceae). Blumea 54: 181-191. http://dx.doi.org/10.1093/jhered/esi026

Hance, H.F. (1868) A pemptade of new Chinese Monochlamydeae. Journal of Botany, British and Foreign, London 6: 47-50. Hatusima, S. (1963) New and noteworthy urticaceous plants from Japan and Formosa II. Journal of Geobotany 12: 34-38. 
Heslopha-Harrison, J. \& Heslopha-Harrison, Y. (1970) Evaluation of pollen viability by enzymatically induced fluorescence: intracellular hydrolysis of fluorescein diacetate. Stain Technology 45: 115-120.

Huelsenbeck, J.P. \& Ronquist, F. (2001) MRBAYES: Bayesian inference of phylogenetic trees. Bioinformatics 17: 754-755. http://dx.doi.org/10.1093/bioinformatics/17.8.754

Jussieu A.L. (1789) Genera plantarum secundum ordines naturales disposita, juxta methodum in Horto Regio Parisiensi exaratum, anno M. DCC. LXXIV. Herissant and Barrois. Paris, pp. 403. http://dx.doi.org/10.5962/bhl.title. 7762

Kanemoto, T. (1997) A possible hybrid between Elatostema oshimense (Hatus.) Yamaz. and E. yonakuniense Hatus. Bulletin of the Botanic Gardens of Toyama 2: 51-57.

Kanemoto, T. \& Yokota, M. (1997) Chromosome numbers of four species of Elatostema (Urticaceae) of the Ryukyus. Journal of Phytogeography and Taxonomy 45: 29-31.

Kitamura, S. (1937) Genera Lactuca, Ixeris and Crepidiastrum. Acta Phytotaxonomica et Geobotanica 6: $235-238$.

Kress, W.J., Wurdack, K.J., Zimmer, E.A., Weight, L.A. \& Janzen, D.H. (2005) Use of DNA barcodes to identify flowering plants. Proceedings of the National Academy of Sciences, USA 102: 8369-8374. http://dx.doi.org/10.1073/pnas.0503123102

Li, D.K., Huang, C.L., Tian, J.B., Wang, Y.K. \& Wang, Y.Q. (2005) Extraction ways of high qualitiful DNA from Z. jujuba Mill. Molecular Plant Breeding 3: 579-583.

Lindley, J. (1821) Collectanea botanica, or Figures and botanical illustrations of rare and curious exotic plants. R. \& A. Taylor, London. http://dx.doi.org/10.5962/bhl.title.6215

Lindley, J. (1828) Streptocarpus rexii. Cape Streptocarpus. Botanical Register 14: pl. 1733.

Linnaeus, C. (1753a) Species Plantarum, Ed 1. Stockholm, Sweden: Imp. Laurentii Salvii.

Linnaeus, C. (1753b) Species Plantarum, Ed 2. Stockholm, Sweden: Imp. Laurentii Salvii.

Maddison, D.R. \& Maddison, W.P. (2000) MacClade 4: Analysis of phylogeny and character evolution. Simauer Associates, Inc., Sunderland, MA, USA.

Miquel, F.A. (1867) Boehmeria. Annales Musei Botanici Lugduno-Batavi 3: 131, pl. 4.

Mogensen, H.L. (1996) The hows and whys of cytoplasmic inheritance in seed plants. American Journal of Botany 83: 383404. http://dx.doi.org/10.2307/2446172

Monro, A.K. (2006) Revision of species-rich genera: A phylogenetic framework for the strategic revision of Pilea (Urticaceae) based on cpDNA, nrDNA, and morphology. American Journal of Botany 93: 426-441. http://dx.doi.org/10.3732/ajb.93.3.426

Nagylaki, T. \& Petes, T.D. (1982) Intrachromosomal gene conversion and the maintenance of sequence homogeneity among repeated genes. Genetics 100: 315-337.

Nees von Esenbeck, C.G.D. (1833) Doellingeria. In: Genera et species Asterearum. Sumtibus Leonardi Schrag, Norimberg, pp. 177-184. http://dx.doi.org/10.5962/bhl.title.46989

Nepi, M., Guarnieri, M., Mugnaini, S., Cresti, L., Pacini, E. \& Piotto, B. (2005) A modified FCR test to evaluate pollen viability in Juniperus communis L. Grana 44: 148-151. http://dx.doi.org/10.1080/00173130510010576

Nickrent, D.L., Schuette, K.P. \& Starr, E.M. (1994) A molecular phylogeny of Arceuthobium (Viscaceae) based on nuclear ribosomal DNA internal transcribed spacer sequences. American Journal of Botany 81: 1149-1160. http://dx.doi.org/10.2307/2445477

Peng, C.I. \& Chiang, T.Y. (2000) Molecular confirmation of unidirectional hybridization in Begonia $\times$ taipeiensis Peng (Begoniaceae) from Taiwan. Annals of the Missouri Botanical Garden 87: 273-285. http://dx.doi.org/10.2307/2666164

Puglisi, C., Wei, Y.G., Nishii, K. \& Moller, M. (2011) Oreocharis $\times$ heterandra (Gesneriaceae): a natural hybrid from the Shengtangshan Mountains, Guangxi, China. Phytotaxa 38: 1-18.

Rhymer, J.M. (2008) Hybridization, introgression, and the evolutionary management of threatened species. In: Carroll, S. \& Fox, C. (eds.) Conservation biology: evolution in action. Oxford University Press, New York, pp. 130-140.

Saito, Y., Kokubugata, G. \& Moller, M. (2007) Molecular evidence for a natural hybrid origin of Doellingeria $\times$ sekimotoi (Asteraceae) using ITS and matk sequences. International Journal of Plant Sciences 168: 469-476. http://dx.doi.org/10.1086/511831

Saito, Y., Moller, M., Kokubugata, G., Katsuyama, T., Marubashi, W. \& Iwashina, T. (2006) Molecular evidence for repeated hybridization events involved in the origin of the genus $\times$ Crepidiastrixeris (Asteraceae) using RAPDs and ITS data. Botanical Journal of the Linnean Society 151: 333-343. http://dx.doi.org/10.1111/j.1095-8339.2006.00513.x

Sang, T., Crawford, D.J. \& Stuessy, T.F. (1995) Documentation of reticulate evolution in Peonies (Peonia) using internal transcribed spacer sequences of nuclear ribosomal DNA-implications for biogeography and concerted evolution. Proceedings of the National Academy of Sciences, USA 92: 6813-6817. http://dx.doi.org/10.1073/pnas.92.15.6813 
Schröter, H. \& Winkler, H. (1935) Monographie der gattung Elatostema s. l:: Allgemeiner teil. Repertorium specierum novarum regni vegetabilis 83 : 1-71. http://dx.doi.org/10.1002/fedr.19380451702

Sears, B. (1980) Review: elimination of platids during spermatogenesis and fertilization in the plant kingdom. Plasmid 4: 233255. http://dx.doi.org/10.1016/0147-619x(80)90063-3

Shao, Q. (2008) Systematics of Elatostema (Urticaceae) and taxonomic revision of Pellionia (Urticaceae) from East Asia. PhD thesis, Insititute of Botany, the Chinese Academy of Sciences, Beijing. 120 pp.

Shih, B.L., Yang, Y.P., Liu, H.Y. \& Lu, S.Y. (1995) Notes on Urticaceae of Taiwan. Botanical Bulletin of Academia Sinica 36: 155-168.

Smith, G. (1974) Unequal crossover and the evolution of multigene families. Cold Spring Harbor Symposia on Quantitative Biology 38: 507-513. http://dx.doi.org/10.1101/sqb.1974.038.01.055

Soltis, D.E. \& Kuzoff, R.K. (1995) Discordance between nuclear and chloroplast phylogenies in the Heuchera group (Saxifragaceae). Evolution 49: 727-742. http://dx.doi.org/10.2307/2410326

Soltis, D.E. \& Soltis, P.S. (1993) Molecular data and the dynamic nature of polyploidy. Critical Reviews in Plant Sciences 12 : 243-273. http://dx.doi.org/10.1080/07352689309701903

Soltis, P.S. \& Soltis, D.E. (2009) The role of hybridization in plant speciation. Annual Review of Plant Biology 60: 561-588. http://dx.doi.org/10.1146/annurev.arplant.043008.092039

Swofford, D.L. (2002) PAUP*: Phylogenetic analysis using parsimony (*and other methods). Sinauer Associates Inc., Sunderland, MA, USA.

Thompson, J.D., Gibson, T.J., Plewniak, F., Jeanmougin, F. \& Higgins, D.G. (1997) The CLUSTAL_X windows interface: flexible strategies for multiple sequence alignment aided by quality analysis tools. Nucleic Acids Research 25: 4876-4882. http://dx.doi.org/10.1093/nar/25.24.4876

Wang, W.T. (1980) Classificatio specierum Elatostematis (Urticaceae). Bulletin of Botanical Laboratory of North-Eastern Forestry Institute 4: 1-96.

Wang, W.T. (2012) Nova classification specierum sinicarum Elatostematis (Urticaceae). In: D. Z. Fu (ed.) Paper collection of W. T. Wang. Higher eduction press, Beijing, pp. 1016-1178.

Weddell, H.A. (1869) Urticaceae, In: De Candolle A. (ed.) Prodomus Systematis Naturalis Regni Vegetabilis, 16 (1). Masson, Paris, pp. 32-35.

Wendel, J.F., Schnabel, A. \& Seelanan, T. (1995) Bidirectional interlocus concerted evolution following allopolyploid speciation in cotton (Gossypium). Proceedings of the National Academy of Sciences, USA 92: 280-284. http://dx.doi.org/10.1073/pnas.92.1.280

Whitney, K.D., Ahern, J.R., Campbell, L.G., Albert, L.P. \& King, M.S. (2010) Patterns of hybridization in plants. Perspectives in Plant Ecology Evolution and Systematics 12: 175-182. http://dx.doi.org/10.1016/j.ppees.2010.02.002

Wright, C.H. (1899) Urticaceae. Journal of Linnean Society, Botany, London 26: 485.

Yahara, T. (1983) A biosystematic study on the local populations of some species of the genus Boehmeria with special reference to apomixis. Journal of the Faculty of Science, University of Tokyo, Section III, Botany 13: 217-262.

Yamasiki, T. (1972) Supplement of the flora of Ryukyu and Formasa. Journal of Japanese Botany 47: 179-180.

Yang, Y.P., Shih, B.L. \& Liu, H.Y. (1995) A revision of Elatostema (Urticaceae) of Taiwan. Botanical Bulletin of Academia Sinica 36: 259-279.

Zhang, Q., Liu, Y. \& Sodmergen (2003) Examination of the cytoplasmic DNA in male reproductive cells to determine the potential for cytoplasmic inheritance in 295 angiosperm species. Plant and Cell Physiology 44: 941-951. http://dx.doi.org/10.1093/pcp/pcg121 